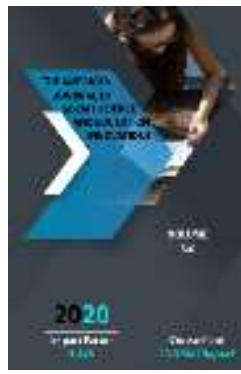

\title{
Use Of Interactive Methods In Teaching Foreign Language (Russian) To Veterinary Students
}

\author{
Ishanova Nargis Rakhmatovna \\ Teacher Of Russian Language Tashkent Branch Of SAMVMI, Uzbekistan
}

\begin{abstract}
Journal Website: http://usajournalshub.c om/index,php/tajssei

Copyright: Original content from this work may be used under the terms of the creative commons attributes 4.0 licence.
\end{abstract}

\section{ABSTRACT}

Focusing on interactive methods in foreign language teaching increases the effectiveness of teaching and broadens the student's horizons along with language learning. This article provides students majoring in veterinary medicine with a comprehensive analysis of the innovative ideas of foreign language (Russian) language, analytical ideas on interactive methods on the example of foreign and national experience, and the authors of the existing problem.

\section{KEYWORDS}

Non-interactive methods, Russian grammar, interactive methods, specialization in veterinary medicine.

\section{INTRODUCTION}

It is known that there is a growing interest in the introduction of innovative technologies and interactive methods in foreign language teaching. Because the use of such methods with interactive projects increases the efficiency and effectiveness of education, increases the motivation of students to learn. The resolution on measures to further improve the system of learning foreign languages states that "through the introduction of advanced teaching methods using modern pedagogical and information and communication technologies, the younger generation will be able to learn foreign languages. One of the important tasks is to radically improve the system of education, training of fluent speakers of these languages and, on this basis, to create conditions and opportunities for their achievements in world civilization and the wider use of world information resources, international cooperation and dialogue[1]- is 
not mentioned in vain. According to the resolution, interactive methods using innovative technologies in teaching foreign languages have been introduced in our country. The word innovation is derived from the English word "innovation". That is, the use of interactive forms aimed at increasing the effectiveness of the educational process on the basis of innovations, rather than on the basis of established norms, as in the traditional system of education. Focusing on interactive methods in foreign language teaching increases the effectiveness of teaching and broadens the student's horizons along with language learning.

Today, our teachers use the following innovative methods in the proper organization of Russian language classes for students of veterinary medicine, based on the experience of teachers of foreign languages in the United States and the United Kingdom:

- In order to use this method, the beginning of the story is read and the students are judged on how it ends. [2]

- Quick answers help to increase the effectiveness of the lesson; - "Warm-up exercises" - the use of various games in the classroom to engage students in the lesson;

- "Pantomime" this method can be used in a lesson where very difficult topics need to be explained, or when students are tired of writing exercises;

- The method of "a chain story" helps to develop students' oral skills;

- "Acting characters" This method can be used in all types of lessons. Professionals such as Interpreter, Translator, Writer, Poet can participate in the lesson and talk to students;

- The "When pictures speak" method is more convenient and helps to teach Russian, to develop students' oral speech, it is necessary to use thematic pictures;
- Quiz cards are distributed according to the number of students and allow all students to attend classes at the same time, which saves time. [3]

As we have seen, each innovative method has its own advantages. All of these methods involve collaboration between teacher and student, ensuring the active participation of the student in the educational process. The purpose of learning any foreign language is to be able to communicate fluently in that language.

The process of informatization of higher education is carried out with the help of electronic educational resources, information systems of the Republic. The analysis of methodological literature [3] identified the following advantages of the use of ICT in the teaching of Russian (foreign) language to students of veterinary specialties: improving the quality and efficiency of the educational process; increase the activity of students' educational activities; implementation of interdisciplinary links; increase the volume and optimize the search for the required information; to create a unique educational environment for students, taking into account their level of knowledge and individual trajectory. [4]

Teaching and learning foreign languages is a long and perfect process. It requires constant work and self-improvement. It is clear that the use of various interactive games in the process of teaching foreign languages to improve oral skills makes learning a foreign language not boring, but a fun and favourite activity. [5,6] Interactive Games encourage language learners to behave more freely, even shy students. It is effective to use interactive games, especially to increase grammar and vocabulary. However, before using these games, the teacher must clearly explain to the students the purpose of the game, the rules of the game and closely relate it to the topic. The interactive games included in this set of methodological 
recommendations are a useful source of oral instruction for students majoring in veterinary medicine studying Russian.

In short, as a result of the use of innovative methods in Russian language lessons students develop logical thinking skills, improve speech, and develop the ability to respond quickly and accurately. Such methods stimulate the student's interest in knowledge. Students are also encouraged to prepare well for class. This makes learners active participants in the learning process.

As the education system aims to nurture a free-thinking, well-rounded, mature person, in the future we must further strengthen the effective use of innovative technologies and put into practice new forms of interactive methods. The following methods can be suggested in addition to the effective interactive organization of Russian language lessons:

1. Thinking about the subject, improving speech through "word games";

2. Work with small audiences of five or six people; (This will improve the quality of the lesson and improve the teacher's approach to the student)

3. "Free interview preparation" This method improves the student's speaking skills and improves the culture of quick communication.

All of the above suggestions will help to educate young people who are interested in learning a foreign language, both spiritually and physically.

\section{REFERENCES}

1. http://www.lex.uz/docs/-2126032

2. Titova S. V., Kharlamenko I. V. Method sovmestnogo napisaniya esse i ix vzaimnogo otsenivaniya pri obuchenii pismenno-rechevym umeniyam // Vestnik Moskovskogo Universiteta. Series 19. Linguistics and intercultural communication. 2017. № 3. S. 26-40.
3. Eyler, J. Reektion: Linking Servike and Learning-Linking Students and Communities // Journal of Social Issues 58, 2002. - pp. 517-524.

4. New dictionary of methodical terms and concepts (theory and practice of writing). [Electronic resource]. - URL: method_terms. academic.ru

5. Husniddin Usmanaliyev Extensive use of ICT tools and methods in foreign language teaching Page 54 Nodirabegim Publishing House, 2019.

6. Burimskaya D. V., Kharlamenko I. V. Kompleksnyy podkhod pri obuchenii studentov neyazykovyx fakultetov inostrannomu yazyku na baze informatsionnyx sistem // Vestnik Moskovskogo gosudarstvennogo oblastnogo Universiteta. Series: Pedagogy. 2019. № 2. S. 96-111. 